\title{
Inkorporowanie modeli z dziedziny fizyki, matematyki i neurobiologii na grunt lingwistyki antropocentrycznej
}

\author{
Applying Physical, Mathematical and Neurobiological Models into Linguistic Research
}

\author{
Anna BAJEROWSKA \\ Uniwersytet Warszawski/ University of Warsaw \\ E-mail: a.b.bajerowska@uw.edu.pl
}

\begin{abstract}
The objective of this paper is twofold. First, a novel multidisciplinary model will be outlined, which was built across anthropocentric linguistics, quantum physics and neurobiology and which is aimed at offering a possible solution to the problem of human text pattern recognition. It has to be highlighted that the present considerations are preliminary. Second, a conceptual introduction to the multidisciplinary approach to modeling in linguistics in the light of the anthropocentric theory of human languages will be provided.
\end{abstract}

Keywords: anthropocentric theory of human languages, correlative models of knowledge, quantum correlations, quantum state, text patterns, verbal reference, state vector, quantum svstem

\section{Wstęp}

Postulat wyłonienia ontogenetycznie uwarunkowanych współczynników determinujących ludzkie właściwości językowe nabiera szczególnego znaczenia w kontekście rozważań osadzonych w perspektywie lingwistyki antropocentrycznej (por. F. Grucza 1993, 1997; S. Grucza 2007, 2008). Pojęciowe wyodrębnienie wyrażeniowej oraz mentalnej postaci tekstów (zob. S. Grucza 2007, 2008) stworzyło właściwe tło teoretyczne dla usystematyzowania prób modelowania na styku lingwistyki oraz dyscyplin ścisłych, uwzględniającego biofizyczne aspekty natury językowych właściwości ludzi. Zarys modelu realizacji tekstemów skonstruowany w oparciu o koncepcję korelacji kwantowych i korelatywnych modeli wiedzy zaprezentowany w niniejszym artykule, stanowi próbę realizacji wspomnianego postulatu.

\section{Multidyscyplinarny model realizacji tekstemów}

Wśród modeli ludzkiej rzeczywistości językowej powstałych na styku lingwistyki i nauk ścisłych na uwagę zasługuje koncepcja fizyka matematycznego R. Penrose'a (zob. R. Penrose 1995, 1997, 2000), rozszerzona przez M. Bogusławską-Tafelską (zob. M. Bogusławska-Tafelska 2008) o elementy eksplikatywne. Punkt odniesienia stanowi dlań kluczowe dla paradygmatu kwantowego w fizyce zjawisko superpozycji. 
Idea superpozycji bazuje na założeniu, że pozycja cząsteczki w stanie kwantowym ${ }^{1}$ określona jest za pomocą funkcji falowej opisującej zbiór wartości odpowiadających potencjalnym stanom danego układu, a nie jedną mierzalną algorytmicznie wartość, przy czym cząsteczka zachowuje integralność (zob. M. Bogusławska-Tafelska 2008: 204, R. Penrose 1995: 260 i nast.). Ponieważ właściwości językowe umożliwiają ludziom sformułowanie określonej wypowiedzi na nieskończenie wiele sposobów, M. Bogusławska-Tafelska wnioskuje, iż zamiar sformułowania przez człowieka tekstu znajduje swą realizację w obrębie zbioru możliwych rozwiązań (zob. M. Bogusławska-Tafelska 2008: 206).

Skonfrontowanie właściwego modelu, adaptowanego z dziedziny fizyki, z innym, skonstruowanym na gruncie lingwistyki, może rzucić na analizowany fragment rzeczywistości światło uwzględniające biofizyczne aspekty jej procesualnej natury. Powyższą hipotezę postaram się przybliżyć, prezentując propozycję eksplikacji procesu realizacji tekstemów na poziomie neurofizjologicznym w oparciu o koncepcję korelacji kwantowych oraz korelatywnych modeli wiedzy.

Przyjęcie perspektywy funkcjonalnej w modelowaniu neurobiologicznym pozwoliło uchwycić dynamiczną naturę wiedzy ludzkiej oraz wytworzyć dystans wobec paradygmatu opartego na idei tzw. sztywnych struktur i poglądach lokacjonistycznych. Podejście funkcjonalne odsłoniło spójną dynamikę wiedzy, manifestującą się poprzez synchronizację efektów aktywności neuronalnej w danym czasie. W perspektywie funkcjonalnej konstruowane są korelatywne modele wiedzy (zob. A.R. Damasio 1989, E. Linz 2002), bazujące na idei korelacji czasowej procesów neuronalnych. W konsekwencji założenia dotyczące konkretnej lokalizacji wiedzy w mózgach ludzkich ustąpiły miejsca idei syntezy informacji następującej w czasie, lecz bez zachowania spójności przestrzennej przebiegu procesów (zob. A. Bajerowska 2014: 27).

Pewne zakresy wiedzy stanowią tekstemy (wzorce tekstów), zinternalizowane w mózgach mówców-słuchaczy w wyniku nabywania przez nich doświadczeń w dziedzinie komunikacji werbalnej (zob. S. Grucza 2008: 170 i nast.). W. Heinemann stwierdza, że są one ,(...) podzbiorami wiedzy interakcyjnej uczestników komunikacji. Stanowią uwarunkowane społecznie, zinterioryzowane przez jednostki, konwencjonalne schematy/ wzorce, które odnoszą się do kompleksowych całości interakcyjnych i tekstowych" (W. Heinemann 2009: 88).

W. Heinemann podkreśla, że wzorce tekstów (tekstemy) nie wykazują własności statycznych. Właściwa jest im natomiast dynamika, gdyż są one (zazwyczaj systematycznie) aktywowane podczas aktów komunikacji zdeterminowanych przez określony cel komunikacyjny (zob. A. Bajerowska 2014: 91 i nast.).

Przebieg procesów rozumienia oraz generowania tekstów ma charakter kompleksowy (zob. S. Grucza 2008, 2015, W. Heinemann 2009). Skategoryzowanie jednego

${ }^{1}$, ,...) w mechanice kwantowej każde dopuszczalne położenie cząstki jest dla niej pewną możliwością. (...) wszystkie możliwości trzeba w pewien sposób połączyć, przypisując im zespolone wagi. Zbiór zespolonych wag opisuje kwantowy stan cząstki; traktuje się go jako zespoloną funkcję położenia zwaną funkcją falową cząstki." (R. Penrose 2000: 274). Jest to zatem informacja o układzie kwantowym, która pozwala określić prawdopodobieństwa wyników każdego pomiaru, jakiego można na tym układzie dokonać. 
specyficznego elementu pociąga za sobą zidentyfikowanie „wzorca globalnego”, a zatem implikuje możliwość predykcji względem przebiegu realizacji tekstemu (zob. W. Heinemann 2009: 85).

Przyjąwszy, że dany tekstem będący inherentnym komponentem języka/ właściwości językowych konkretnego mówcy-słuchacza, stanowi w biofizycznym wymiarze swego istnienia kompleks możliwych dróg reagowania neuronów na bodźce generujące informacje dot. pragmatycznego, semantycznego czy też syntaktycznego kształtu odbieranego tekstu, wolno założyć, że stan kwantowy tego zespołu układów reagowania neuronalnego można uznać za sieć potencjalności (por. A. Shimony 1997: 150 i nast.). Próby wyjaśnienia jednocześnie precyzyjnej i elastycznej korelacji w obrębie strategii doboru reguł syntaktycznych, pragmatycznych itp. zapewniającej spójną aktywizację określonych komponentów danego tekstemu, adekwatnych względem rodzaju bodźca, można moim zdaniem podejmować w oparciu o koncepcję korelacji kwantowych. Wektor stanu ${ }^{2}$ całego układu dróg reagowania neuronalnego (jego aspektów pragmatycznych, syntaktycznych itd., które podczas realizacji biofizycznej tekstemu przyjmują konkretne wartości w postaci aktywizacji neuronów według określonego wzorca) jest wielkością holistyczną uzależnioną od stanów poszczególnych jego komponentów (stanów intraneuronalnych zaistniałych w wyniku reakcji np. na pragmatyczne, syntaktyczne właściwości bodźca), wzajemnie ze sobą skorelowanych, przy czym żaden $\mathrm{z}$ nich nie jest $\mathrm{w}$ czystym stanie kwantowym ${ }^{3}$. Kiedy $\mathrm{w}$ wyniku zainicjowania procesu realizacji danego tekstemu, np. w wyniku reakcji receptorów podmiotu na warstwę wyrażeniową konkretnego tekstu, dochodzi do aktualizacji zmiennej A w obrębie jednego z komponentów układu (zmienna przybiera konkretną wartość, czyli neurony wchodzą w stan właściwy oddziaływaniu określonej właściwości aspektu danego bodźca, w wyniku czego rozpoczyna się konkretyzacja tekstemu np. w wymiarze syntaktycznym), to jednocześnie - praktycznie bez opóźnienia w czasie - następuje aktualizacja zmiennej B w obrębie komponentu $\mathrm{z}$ nim skorelowanego (ibid.), przy czym spójność funkcjonalna obu aktualizacji ujawnia się w wymiarze adekwatności procedury aktualizacji względem wytworzonego wcześniej, aktywizującego się wzorca reakcji neuronalnej.

Ustalenie amplitud prawdopodobieństwa wystąpienia określonej reakcji neuronów na działanie określonej właściwości bodźca pozwoliłoby przewidzieć, w jaki sposób będzie ewoluował proces realizacji danego tekstemu (zob. R. Penrose 2000: 266 i nast.). Pragnę zaznaczyć, że zaproponowana koncepcja neurofizjologicznej aktualizacji tekstemów prawdopodobnie znajduje swą prymarną płaszczyznę realizacyjną w skali mikro, czyli na poziomie intraneuronalnym, w postaci pulsacyjnych ruchów dimerów (par białek) wewnątrz cytoszkieletów neuronów, warunkujących oscylację kwantową w obrębie całych układów neuronów. Fakt ten wyjaśniałby zdolność neuronów do funkcjonalnie i temporalnie spójnego różnicowania w obrębie aspektualnych wymiarów działania bodźca, bez konieczności sekwencyjnego angażowania kolejnych areałów neuronów. Podobny model mógłby stanowić narzędzie ustalania

\footnotetext{
${ }^{2}$ Wielkość matematyczna opisująca stan kwantowy konkretnego układu.

${ }^{3}$ Pełna informacja dotycząca prawdopodobieństwa wyników wszystkich pomiarów możliwych do przeprowadzenia na danym układzie kwantowym.
} 
zależności w obrębie relacji na płaszczyźnie aktualizacji poszczególnych zmiennych oraz identyfikacji ich potencjalnych korelatów na poziomie strukturalnym tekstów. Umożliwiłby on tym samym predykcję ewentualnych sposobów optymalizacji konstruowania poszczególnych rodzajów tekstów (por. S. Grucza 2015).

\section{Modele multidyscyplinarne w perspektywie lingwistyki antropocentrycznej}

W kontekście zaprezentowanego szkicu nasuwa się wniosek, iż to właśnie pojęciowe wyodrębnienie rzeczywistości idiolektalnej w teorii antropocentrycznej stwarza właściwy kontekst teoretyczny dla integracji wysiłków modelowania czysto lingwistycznego oraz teoretyzacji podejmowanej w oparciu o adaptację (fragmentów) modeli zaczerpniętych z innych dyscyplin. Dzieje się tak, gdyż płaszczyzna „,idio” pozwala spojrzeć na pewne aspekty ludzkiej rzeczywistości językowej z perspektywy praw opisujących jej funkcjonowanie w wymiarze biofizycznym.

Osnowę teoretyczną powyższej propozycji modelowania wybranych aspektów ludzkiej rzeczywistości językowej w oparciu o elementy teorii sformułowanych na gruncie fizyki stanowi ostre rozgraniczenie pomiędzy sferą denotatywną a wyrażeniową tekstów, zaproponowane przez Sambora Gruczę. Istotę dyferencjacji sformułowanej przez Autora „Lingwistyki języków specjalistycznych” (zob. S. Grucza 2008: 188) stanowi odróżnienie ,tekstu” ujmowanego jako zeksternalizowane, materialnie zrealizowane wyrażenie językowe od jego znaczenia, a zatem od tego, do czego jego twórca odnosi je podczas aktów referencji werbalnej - czyli, tego, co Sambor Grucza (ibid.) określa mianem tekstu.

Zarysowane wyżej zagadnienie proponuję określić jako problem dychotomiczny w lingwistyce, również z uwagi na jego wyraźne skorelowanie ze specyfiką problematyki oscylującej wokół tzw. dychotomii umysł-ciało. Korelacja owa znajduje odzwierciedlenie zarówno w sferze złożoności obu problemów jak i w spektrum wynikających z nich konsekwencji natury epistemologicznej. Na szczególną uwagę zasługuje aspekt wewnętrznej kompleksowości wyżej zarysowanej dychotomii: jej sedno stanowi przestrzeń współzależności rozpięta pomiędzy tekstami ujmowanymi jako bezpośrednie korelaty procesów neurofizjologicznych zachodzących w ludzkich mózgach a płaszczyzną specyfiki samych procesów w wymiarze zarówno inter- jak i intraneuronalnym. Zręby prezentowanej dychotomii wyznacza zaś pytanie o charakter relacji znamionujących teksty jako mentalne odpowiedniki konkretnych wyrażeń oraz „teksty” jako obiekty o intencjonalnie (konwencjonalnie) ukształtowanej postaci substancjalnej (zob. A. Bajerowska 2014), istniejące autonomicznie względem mózgów swych twórców.

Mimo całej gamy wzajemnych zróżnicowań w wymiarze ontologicznym i relacyjnym warunek zaistnienia zarówno tekstów jak i ,tekstów” stanowi regularne dokonywanie przez podmiot aktów referencji werbalnej. Dlatego, moim zdaniem, dróg prowadzących ku identyfikacji ewentualnych regularności w obrębie relacji konstytuujących zarysowany problem dychotomiczny w obu jego wspomnianych wymiarach należy poszukiwać przede wszystkim w sferze referencyjnej. W odniesieniu do „tekstów” jako obiektów materialnie zrealizowanych wymaga to ustalenia eksponen- 
tów „siły” referencji na płaszczyźnie wyrażeniowej, i to prawdopodobnie nie w postaci konkretnych wyrażeń, lecz regularności na płaszczyźnie relacyjnej w obrębie pewnych specyficznych układów wyrażeń, konstrukcji syntaktycznych itp. Zainicjowanie prób eksplorowania referencji w odniesieniu do tekstów jako mentalnych korelatów procesów neurobiologicznych nie mogłoby znaleźć swego urzeczywistnienia bez ustalenia wielkości parametryzujących to zjawisko $\mathrm{w}$ procedurach obrazowania neurobiologicznego.

Reprezentuję pogląd zakładający, że w powyższym przypadku kluczowym mogłoby okazać się ujęcie kontrastywne, wykorzystujące studium porównawcze obrazów procesów neurofizjologicznych towarzyszących produkowaniu i/ lub recepcji tekstów o krytycznie niskim stopniu fachowości oraz tekstów o wysokim stopniu specjalistyczności. Podstawę sformułowania powyższej hipotezy stanowi fakt, że właściwości analityczno-generatywne mózgów specjalistów, konstytuujące ich idiolekty specjalistyczne, pozwalają na specyficzną bo wysoce precyzyjną referencję werbalną do obiektów świata danej rzeczywistości profesjonalnej, manifestującą się nie tylko na płaszczyźnie np. poszczególnych terminów, lecz całych wzorców współzależności w obrębie np. układów relacji syntaktycznych, semantycznych itp.

Uważam, że próby odnoszenia fragmentów modeli stworzonych na gruncie fizyki i matematyki do rzeczywistości tekstów oraz ,tekstów” należy podejmować z uwzględnieniem nie tyle ich wzajemnej odrębności ontologicznej co właśnie odmienności specyfiki relacji w obrębie referencji i jej ewentualnych eksponentów. Dlatego sądzę, że światy tekstów i ,tekstów” należy rozważać w odrębnych ramach teoretycznych. Tym samym postuluję rozpatrywanie procesualnej natury tekstów w kategoriach oscylacji kwantowych i superpozycji (odpowiadających skali mikro), rzeczywistość „tekstów” proponuję skonfrontować z kontekstami teoretycznymi zapożyczonymi z fizyki klasycznej (opisującymi świat w skali makro), zaś moment eksternalizacji (fizykalnie uchwytnej realizacji) tekstów, czyli produkcji odpowiadających im „tekstów”, uznać za moment przejścia kompleksowego układu superpozycji dimerów ze stanu kwantowego w klasyczny.

Powyższe sugestie mają charakter hipotetyczny, ponieważ teoria łącząca poziom kwantowy z poziomem klasycznym nie została jeszcze sformułowana. Nie jest jednak wykluczone, że w świetle językowych właściwości ludzi to właśnie zidentyfikowanie eksponentów zjawiska referencji werbalnej, rozważone w wymiarze neurofizjologicznym oraz na planie wyrażeniowym, stanowić będzie klucz do uchwycenia specyfiki i własności emergencji na linii tekst - „tekst”, a tym samym szlak wyjaśnienia przedstawionej przeze mnie dychotomii i jej swoistą klamrę w wymiarze kompozycji konceptualnej.

Antropocentrycznie umotywowany podział płaszczyzn desygnatów wyrażenia TEKSTY na kompleksowe, procesualne korelaty operacji językowych w obrębie konkretnych mózgów ludzkich oraz na zeksternalizowane wyrażenia odpowiadające swym korelatom prawem referencji umożliwia adekwatną względem rzeczywistości eksplikację ich wybranych własności, a tym samym właściwą stratyfikację spektrum badawczego lingwistyki. W kontekście podejmowania multidyscyplinarnych wysił- 
ków poznawczych pogłębienie stopnia uszczegółowienia oraz ewentualna modyfikacja tego ostatniego uwarunkowane są adekwatnością doboru rodzaju i zakresu zapożyczanych modeli - adekwatnością względem natury i właściwości tekstów oraz ,tekstów", które mają zostać poddane analizie, a także względem eksploracji ewentualnej emergencji w obrębie ich wzajemnych relacji oraz w zakresie relacji tekstów i odpowiadających im procesów neurofizjologicznych.

Modele będące efektem analizy określonych fragmentów rzeczywistości na gruncie teorii fizycznych i matematycznych opierają się nie tyle na procedurach definiowania na podstawie wiązek cech dystynktywnych, ile na dążeniu do ujmowania badanych obiektów i/ lub zjawisk w kategoriach relacyjnych (nie sposób nie dostrzec tu zbieżności np. ze sporządzaniem modeli tekstów w oparciu o ich cechy prototypowe). Stosowanie modeli zaczerpniętych z fizyki bądź matematyki w eksplorowaniu istoty językowych właściwości ludzi i efektów ich realizacji jest zasadne o tyle, o ile splot wzajemnych relacji pomiędzy zjawiskami bądź obiektami, w obrębie których właściwości te ujawniają się, wykazuje własności analogiczne względem tych ujętych w danym modelu fizycznym czy też matematycznym.

Należy wyraźnie podkreślić, że pomiędzy obiektami odcinka rzeczywistości, w odniesieniu do którego powstał model fizyczny/ matematyczny adaptowany na gruncie lingwistyki, a obiektami odcinka rzeczywistości stanowiącymi przedmiot modelowania lingwistycznego nie musi/ nie może zachodzić relacja izomorficzna. W konsekwencji pojęcia (a zatem także modele) lingwistyczne sui generis nie są redukowalne do pojęć (modeli) wspomnianych dziedzin nauki (zob. N. Cartwright 1997: 161). Warunek efektywności modelowania multidyscyplinarnego stanowi natomiast istnienie logicznej równoważności w obrębie relacyjnych uwarunkowań obu branych pod uwagę odcinków rzeczywistości. Podążanie tropem wyznaczonym przez tok rozumowania S. Hawkinga (1997) i N. Cartwright (1997) mogłoby zatem zaowocować stwierdzeniem, że modelowanie komponentów ludzkiej rzeczywistości językowej w oparciu o zaadaptowane konstrukty teoretyczne nie oznacza, że komponenty te w pełni odpowiadają założeniom dotyczącym rzeczonych konstruktów, a jedynie, że istnieje logiczna równoważność pomiędzy (tu odniosę się do moich wcześniej przedstawionych postulatów) np. materialną realizacją poszczególnych tekstów a specyfiką przechodzenia cząsteczek ze stanu kwantowego w klasyczny. A zatem dążenie do mimetycznego odwzorowania wybranych aspektów analizowanego fragmentu rzeczywistości w obrębie założeń adaptowanego modelu może okazać się zgubne dla jego potencjału prognostycznego. Zaprezentowane wyżej spojrzenie na modelowanie (także to realizowane na styku odmiennych dyscyplin naukowych) pozwala wysnuć wniosek, iż wysoki stopień sformalizowania modelu bywa odwrotnie proporcjonalny do siły jego potencjału prognostycznego - zwłaszcza w przypadku obszarów rzeczywistości podlegających dynamicznym, wielowymiarowym przeobrażeniom, takich jak językowe właściwości ludzi.

Podsumowując, pragnę podkreślić, że (zwłaszcza na inicjalnym etapie modelowania na styku lingwistyki i nauk ścisłych) pożądane jest podejście badawcze zakładające pluralizm metodologiczny, istotny ze względu na konieczność naukotwórczo efektywnej stratyfikacji analizowanej rzeczywistości (por. M. Bogusławska-Tafelska 
2008: 200 i nast.). Realizacja zadań poznawczych na gruncie nauki wymaga bowiem zniuansowanego, metodologicznie usystematyzowanego wglądu w analizowany fragment rzeczywistości, co nabiera szczególnego znaczenia w odniesieniu do bogatej stratyfikacji ludzkiej rzeczywistości językowej i wielopłaszczyznowego schierarchizowania strukturalnego organizmów ludzkich. Na przebieg dyskusji skupionej wokół zagadnienia unifikacji metodologicznej przełomowy wpływ wywrze moim zdaniem weryfikacja potencjału aplikatywnego i prognostycznego modeli multidyscyplinarnych. Prawdopodobnie zaowocuje ona nie tyle unifikacją metod stosowanych dotychczas, ile poszukiwaniem nowych formuł metodologicznych, dostosowanych do własności analizowanej rzeczywistości, wyodrębnionych w efekcie konstruowania teorii w oparciu o modele hybrydowe.

\section{Bibliografia}

Bajerowska, A. (2014), Transferencja wiedzy specjalistycznej (Studi@ Naukowe 24). Warszawa.

Blackmore, S. (2003), Consciousness. London.

Bogusławska-Tafelska, M. (2008), Kwantowa natura języka. Modele hybrydowe w studiach nad umystem i językiem, (w:) A. Kiklewicz/ J. Dębowski (red.), Język poza granicami języka. Olsztyn, 197-209.

Cartwright, N. (1997), Dlaczego fizyka?, (w:) R. Penrose (red.), Makroświat, mikroświat i ludzki umysł. Warszawa, 159-165.

Damasio, A.R. (1989), Concepts in the brain, (w:) "Mind and Language" 4, 24-28.

Grucza, F. (1993), Język, ludzkie właściwości językowe, językowa zdolność ludzi, (w:) J. Piontka/ A. Wiercińska (red.), Człowiek w perspektywie ujęć biokulturowych. Poznań, 151-174.

Grucza, F. (1997), Języki ludzkie a wyrażenia językowe, wiedza a informacja, mózg a umyst ludzki, (w:) F. Grucza/ M. Dakowska (red.), Podejścia kognitywne w lingwistyce, translatoryce i glottodydaktyce. Warszawa, 7-21.

Grucza, S. (2007), Od lingwistyki tekstu do lingwistyki tekstu specjalistycznego. Warszawa.

Grucza, S. (2008), Lingwistyka języków specjalistycznych. Warszawa.

Grucza, S. (2015), Języki jako „instrumenty” predykcji wiedzy przyszłości, (w:) A. Duszak/ A. Jopek-Bosiacka/ G. Kowalski (red.), Tekst naukowy i jego przekład. Kraków, 53-77.

Hawking, S. (1997), Zastrzeżenia bezwstydnego redukcjonisty, (w:) R. Penrose (red.), Makroświat, mikroświat i ludzki umysł. Warszawa, 166-169.

Heinemann W. (2009), Rodzaj tekstu - wzorzec tekstu - typ tekstu, (w:) Z. Bilut-Homplewicz/ W. Czachur/ M. Smykała (red.), Lingwistyka tekstu w Niemczech. Pojęcia, problemy, perspektywy. Wrocław, 69-96.

Lakoff G. (2011), Kobiety, ogień i rzeczy niebezpieczne. Kraków.

Linz, E. (2002), Indiskrete Semantik. Kognitive Linguistik und neurowissenschaftliche Theoriebildung. München.

Penrose, R. (1995), Shadows of the mind. London. 
Penrose, R. (1997), Makroświat, mikroświat i ludzki umyst. Warszawa.

Penrose, R. (2000), Nowy umyst cesarza. O komputerach, umyśle i prawach fizyki. Warszawa.

Schrödinger, E. (1998), Czym jest życie? Fizyczne aspekty żywej komórki. Umyst $i$ materia. Szkice autobiograficzne. Warszawa.

Shimony, A. (1997), O zjawiskach umystowych, mechanice kwantowej i aktualizacji potencjalności, (w:) R. Penrose (red.), Makroświat, mikroświat i ludzki umysł. Warszawa, 143-158. 